\title{
PRESIDEN INDONESIA TIGA PERIODE
}

\author{
Oleh: \\ Pin Pin ${ }^{1)}$ \\ Jannus Timbo Halomoan Siahaan ${ }^{2)}$ \\ Bertha Nellya ${ }^{3)}$ \\ Matius Bangun ${ }^{4}$ \\ Universitas Darma Agung, Medan 1,2,3,4) \\ E-mail: \\ drpinpin62@gmail.com ${ }^{1)}$ \\ Jannus.siahaan@gmail.com $^{2}$ \\ nellyabertha@gmail.com ${ }^{3}$ \\ $\underline{\text { Udastudi28@gmail.com }}^{4)}$
}

\begin{abstract}
This study aims at exploring the possibility of enacting a three-term term of office of the President of Indonesia by taking into account the existing laws. Restrictions on Indonesian President to assume the term of office for the two periods is the effort of the people through the Assembly to prevent the President of Indonesia holds the power exceeding 10 years, in order to avoid the abuse of power or authorization of the parties in carrying out the task. This research is a descriptive study by collecting data from books, news media, previous research journals, and applicable laws. The results of the study found that if the people wanted, the law could be changed as needed.
\end{abstract}

Keywords: President of Indonesia, Three Periods

\begin{abstract}
ABSTRAK
Penelitian ini bertujuan untuk mencari kemungkinan diberlakukan masa jabatan Presiden Indonesia tiga periode dengan memperhatikan Undang-Undang yang sudah berlaku. Pembatasan Presiden Indonesia untuk memangku masa jabatan untuk dua periode adalah upaya dari rakyat melalui MPR untuk mencegah Presiden Indonesia memegang kekuasaan melebihi waktu 10 tahun, agar dapat terhindar dari penyalahgunaan kekuasaan maupun otorisasi dari satu pihak dalam menjalankan tugas. Penelitian ini adalah penelitian deskriptif dengan pengumpulkan data dari buku, media kabar, jurnal-jurnal penelitian sebelumnya, dan perundangan yang berlaku. Hasil penelitian menemukan bahwa jika rakyat menghendaki, maka undang-undang bisa dirubah sesuai keperluan.
\end{abstract}

Kata Kunci: Presiden Indonesia, Tiga Periode

\section{PENDAHULUAN}

Saat ini ramai didiskusikan tentang kemungkinan Presiden Indonesia dilakukan tiga periode, wacana ini menimbulkan pro dan kontra.

Pada hari selasa yaitupada tanggal 19Oktober 1999, MPR RI memutuskan untuk membatasi masa jabatan Presiden RI yaitu dari yang sebelumnya tidak terbatas, menjadi masa jabatan untuk dua periode saja.

Penelitian ini berusaha untuk mencari kemungkinan diberlakukan masa jabatan Presiden Indonesia tiga periode dengan memperhatikan Undang-Undang yang sudah berlaku. 


\section{METODE PENELITIAN}

Metode penelitian jurnal ini adala penelitian kualitatif dengan metode deskriptif analisis. Upaya pengumpulan data penelitian ini merupakan studi kepustakaan dengan cara pengumpulkan data dari buku, media kabar, maupun jurnal-jurnal dari penelitian-penelitian sebelumnya. Fokus dari penulisan ini adalah perubahan Undang-Undang Dasar yang mendasari penentuan masa jabatan Presiden dibatasi sebanyak dua kali saja.

Pasal 7 Undang-Undang Dasar Negara Republik Indonesia, ditetapakan di Jakarta merupakan perubahan pretama UndangUndang Dasar Negara Republik Indonesia yang ditetapkan pada tanggal 19 Oktober 1999, yang isinya :

Presiden dan Wakil Presiden Indonesia memegang jabatan selama lima tahun, dan sesudahnya dapat dipilih Kembali dalam jabatan yang sama, hanya untuk satu kali masa jabatan saja.

Sejarah dunia tentang terjadinya

Sejarah dunia tentang terbjadinya pembatasan masa jabatan Presiden dimulai pada masa pemilihan Presiden di Amerika Serikat, pada tahun 1796 George Washington pada masa itu memangku jabatan sebagai Presiden pertama Amerika Serikat, dimana George Washington berusaha membuat kebijakan yang tidak tertulis ketika dirinya menolak untuk menerima masa jabatannya yang ketiga.
Karena kebijakan George Washington akan masa jabatan seorang Presiden Amereika Serikat tersebut tidak tertuang dalam Undang-Undang Amerika, maka Franklin D. Roosevelt terpilih sampai 4 periode karena kekosongan konstitusitentang masa jabatan seorang Presiden, maka terjadilah Franklin D. Roosevelt memangku jabatan Presiden dari tahun 1932-1944. Pada Kongres Amerika Serikat tahun 1947, terbit Undang-Undang tentang pembatasan dua periode masa jabatan seorang Presiden Amerika.Pada saat itu Kongres berusaha mengusukkan pada Amandemen yang ke 22, dan secara resmi Kongres memutuskan untuk membatasi masa jabatan Presiden Amerika Serika untuk hanya memangku dua masa jabatan dan selama empat tahun dalam satu periode.

\section{HASIL DAN PEMBAHASAN}

Pernyataan Amien Rais terkait wacana masa jabatan tiga periode disampaikan melalui pada Sabtu 13 Maret 2021, dimana menurut Amien, rencana mengubah ketentuan masa jabatan Presiden menjadi tiga periode tersebut akan dilakukan dengan cara menggelar Sidang Istimewa melalui MPR, agar dapat mengubah atau mengamendemen UUD 1945 RI., dimana mungkin 1 atau 2 pasal yang diusahakan untuk diperbaiki, lanjut Amien Rais dalama tayang Kompas TV pada hari Seinin, $\quad 15 \quad$ Maret 2021. 
Tetapi pernyataan Amien Rais tentang wacana Jokowi yang akan berusaha mengubah masa jabatan Presiden Republik Indonesia menjadi tiga periode tersebut, dibantah langsung oleh jurubicara Jokowi. Fadjroel Rachman selaku juru-bicara resmi Presiden dengan tegas mengatakan bahwa Presiden akan tegak lurus pada Konstitusi UUD 1945, dan masa jabatan Presiden Indonesia adalah dua periode.

Salah satu peraturan pembatasan kekuasaan Presiden dimana menegaskan pembatasan terhadap masa jabatan Presidendan Wakil Presiden,tertuang di pasa ke 7 dari UUD 1945., namun pada masa lalu ternyata pengaturan pada pasal 7 tersebut tidak diikuti dengan pengaturan batasan atas masa jabatan Presiden RI serta Wakil Presiden RIdi Indonesia. Sehingga pada prakteknya terjadi pemilihan pengulangan Presiden yang sama dipilih kembali secara terus menerus, kondisi ini jelas tidak mengakui konstitusi Indonesia yang sudah tertuang dalam UUD 1945, sejarah masa kepemimpinan Ir. Soekarno dan Soehato dalam periode lebih dari dua atas kali masa jabatan secara berturutturut, dimana Soekarno berkuasa selama 21 tahun. Terjadinya hal tersebut selain melanggar konstitusi, juga dapat menyalah-gunakan kekuasaan untuk kepentingan pribadi, dan tidak memperhatikan penggantian pemimpin untuk generasi yang selanjutnya.

Ir. Soekarno yang terpilih menjadi Presiden pertama RI pada tanggan 18 Agustus 1945, terus menjabat sebagai Presiden Indonesia sampai terbetnuk Negara Federal RIS (Republik Indonesia Serikat) pada tanggal 27 Desember 1949. Pada masa tersebut pemilihan dilakukan secara aklamasi,, yaitu pernyataan setuju lisan dari seluruh peserta yang hadir, dan terpilihnya kembali Ir. Soekarno sebagai Presiden RI sebagai calon tunggal yang terus berlangsung selama Indonesia sebagai Negara Federal. Dan Ketika Indonesia Kembali kepada UUD 1945, maka otomatis ketentuan peraturan yang ada kembali ke UUD 1945, dan harus dilaksanakan kembali.Tetapi dalam prakteknya tetap terjadi penyimpangan.Contohnya Ketika terbit TAP MPRS no.III/MPRS/1963, yang merupakan penyimpangan dari UUD 1945 , karena mengizinkan pengangkatan kembali Ir. Soekarno seorang pemimpin besar revolusi, menjadi Presiden seumur hidup. TAP MPR tersebut mencerminkan bahwa tidak akan terjadi penggantian maupun peralihan kekuasaan sebagaimana yang telah diatur dalam UUD 1945. Hal ini mencerminkan Ir. Soekarno seperti seorang raja.

Saat terjadi pemberontakan Partai Komunis Indonesia, dimana kondisi 
Indonesia pada saat itu sangat tidak stabli, semua pihak saling curiga, begitu juga kondisi ekonomi yang krisis membuat hidup rakyat sangat menderita. Melihat kondisi tersebut MPRS menerbitkan undang-undang baru MPRS NO. XXXIII/MPRS/1967,yang ditanda-tangani oleh DR. AH. NASUTION, Jendral TNI RI peraturan ini mencabut kekuasaan Presiden/Mandatari MPRS Ir. Soekarno, serta melarang Soekarno melakukan kegiatan politik sampai dengan pemilihan umum, dan Ir. Soekarno digantikan oleh Soeharto yang dilantik pada tanggal 12 Maret 1967.

Tidak terjadi penyimpangan terhadapat UUD 1945 masa jabatan Soehato sebagai Presiden Republik Indonesia, Pada pemilihan Presiden di masa Soeharto juga terjadi calon tunggal Presiden, Soeharto juga dan tidak ada melakukan perubahan terhadap UUD 1945. Adam Malik selaku ketua MPR yang diresmikan pada 1 Oktober 1977, menerbitkan TAP MPR no. 1 / MPR / 1978 mengenai tata tertib MPR yang akan mempertahankan konstitusi dan tidak akan merubah konstitusi berdasarkan Pancasila dan UUD 1945. Tetapi Soeharto sangat jeli dan berhasil memanfaatkan kelemahan yang terdapat PADA UUD 1945, karena pada saat itu pasal 7 UUD 1945 masih kurang detil tentang berapa lama masa jabatan seorang Presiden Indonesia, sehingga Soehato menjabat lebih lama sebagai Presiden Indonesia dibanding Soekarno. Soeharto secara berkelanjutan menjabat selama 32 tahun masa jabatan yang dapat dipilih kembali.

Ketika George Washington akan dipilih kembali untuk ketiga kalinya sebagai Presiden Amerika Serika, George menolak walau pada saat itu konstitusi di Amerika tidak melarang, karena George memandang bahwa sebaiknya tidak terjadi pemegang kekuasaan yang terus menerus, akan tidak disalah-gunakan wewenangnya. Sungguh seorang negawawan yang berjiiwa besar. George yang dijuluki bapak bangsa, tidak haus kekuasaan dan lebih mementingkan pemerintahan yang kuat dan kaya. George diakui sebagai Presiden terbaik.Konstitusi tentang pembatasan masa jabatan Presiden Amerika yang hanya terbatas dua periode baru berlaku pada tahun 1947, 148 tahun setelah George Washongton meninggal.

Buku How democracies die yang terbit tahun 2018 menggambarkan bagaimana pemimpin terpilih di Amerika Serikat dapat secara bertahap menumbangkan proses demokrasi untuk meningkatkan kekuatan pemimpin terpilih tersebut. Steven Levitsky dan Daniel Ziblatt penulis buku tersebut menggambarkan kondisi Amerika Serikat yang tergantung pada kemampuan warga negara aktif dan partaipartai politik untuk membangun normanorma tersembunyi dari permainan 
demokrasi.Adanya potensi muncul politisi otoriter dalam masyarakat demokrasi.Kedua peneliti ini ingin memperkenalkan ide sederhana tentang demokrasi, sebagai kebebasan dan toleransi,.Nilai demokrasi digambarkan bukan hanya sekumpulan aturan, tetapi adalah kondisi kemungkinan untuk menjalani hidup yang bermakna, bebas dan rasa persaudaraan antar sesama.

Kondisi saat dunia sudah mengalami pandemic covid-19 sejak Maret 2019 yang sudah lebih dari dua tahun, membuat rakyat Indonesia yang menamakan diri sebagai Sekretaris Nasional (Seknas) yang mendorong Jokowi untuk maju sebagai calon Presiden yang ketiga kalinya, berdampingan dengan Menteri Pertahanan saat ini Prabowo Subinato, dengan sebutan Jokpro (Jokowi-Prabowo).

\section{SIMPULAN}

UUD 1945 yang disahkan sebagai konstitusi negara Indonesia sehari setelah kemerdekaan Indonesia yaitu tanggal 18 Agustus 1945, sudah dirubah sebanyak 4 (empat kali) .pertama kali pada tahun 1999, kedua kali pada tahun 2000, ketiga kali pada tahun 2001 dan amandemen keempat pada tahun 2002.

Jika MPR pada tahun 1999 bisa merubah Undang-Undang Dasar RI dengan pasal 7 yang menentukan pembatasan masa jabatan Presiden, maka jika kondisi suatu saat mayoritas rakyat Indonesia menginginkan masa jabatan Presidin dirubah menjadi tiga periode, tentu saja itu bisa dilakukan melalui amandemen MPR, dengan mempertimbankan kepentingan semua rakyat, karena segala perubahan dapat dilakukan jika kondisi dan situasi mengizinkan demi kepentingan rakyat.Amandemen dapat dilakukan. Sebanyak 1/3 (sepertiga) usulan anggota MPR diperlukan untuk mengusulkan amandemen menuurt pasal 37 UUD 1945, jika anggota MPR yang ada saat ini 711 orang, maka diperlukan minimal usulan dari 237 orang anggota MPR.

Penelitian ini tidak berfokus untuk perubahan Undang-Undang pada masa ini, tetapi kita memandang jauh ke depan, jika suatu masa diperlukan perubahan masa jabatan Presiden sebanyak tiga kali, sesuai kebutuhan situasi dan kondisi, ekonomi danpolitik, demi kepentingan Bersama.Perubahan masa jabatan Presiden sebanyak tiga periode sangat jauh berbeda dengan masa jabata Presiden seumur hidup yang bercenderung otoritas.

\section{DAFTAR PUSTAKA}

Gelfeld,B (2018). Preventing Deviations from Presidential Term Limits in Low and Middle Income Democracies (Doctoral Dissertion, Pardee Rand Graduate School).https://www.rand.org/pubs/rgs_dis sertations/RGSD419.html 
Thalib, D., \& Hamidi, J. Ni'matul Huda, (2008). Teori dan Hukum Konstitusi, Jakarta: PT RajaGrafindo Persada.

Jurnal Ilmiah, Skripsi, Tesis dan Disertas :

Al Atok.A.R (2016). Penguatan Kependudukan dan Pembatasan Kekuasaan Presiden dalam Perubahan UUD

(http://journal.um.ac.id/index.php/jppk/arti cle/view/5495) Diakses Tanggal 12 Juli 2021

https://jurnal.unpad.ac.id/pjih/article/view/ 10116 Diakses Tanggal 12 Juli 2021

https://journals.sagepub.com/doi/full/10.11 77/0010414019830737 Diakses Tanggal 12 Juli 2021

https://papers.ssrn.com/sol3/papers.cfm?ab $\underline{\text { stract_id=3053521 Diakses Tanggal } 12}$ Juli 2021

https://e-

journal.unair.ac.id/JD/article/view/14254

Diakses Tanggal 12 Juli 2021

https://journals.sagepub.com/doi/full/10.11 77/0010414019830737 Diakses Tanggal 12 Juli 2021

https://tirto.id/sejarah-isi-perubahanamandemen-uud-1945-pertama-tahun1999-ejFQ Diakses Tanggal 5 Juli 2021 https://www.timesindonesia.co.id/read/ne ws/354891/menakar-peluang-jabatanpresiden-tiga-periode Diakses pada tanggal 13 Juli 2021

https://www.hukumonline.com/klinik/detai 1/ulasan/1t506c3ff06682e/pembuatan-
undang-undangDiakses Tanggal 2 Juli 2021

https://www.liputan6.com/global/read/438 5938/alasan-presiden-as-hanya-bisa$\underline{\text { menjabat-selama-4-tahun-dalam-satu- }}$ periodeDiakses Tanggal 2 Juli 2021 https://nasional.kompas.com/read/20 19/10/07/21003041/nasdem-masajabatan-Presiden-perludidiskusikan?page=all Diakses Tanggal 2 Juli 2021 https://nasional.kompas.com/read/2021/03/ $\underline{\text { 15/08430071/amien-rais-sebut-ada- }}$

skenario-jabatan-presiden-jadi-3periode?page $=$ allDiakses Tanggal 5 Juli 2021

https://www.rand.org/pubs/rgs_dissertatio ns/RGSD419.html Diakses pada tanggal 2 Juli 2021

https://tirto.id/amandemen-uud-1945dilakukan-4-kali-sejarah-perubahan-pasal$\underline{\text { f7Cw }}$ Diakses pada tanggal 13 Juli 2021 https://nasional.kompas.com/read/2021/06/ 23/11582111/tolak-wacana-presiden-tigaperiode-demokrat-pandemi-covid-19-takbisa Diakses tanggal 13 Juli 2021 https://www.researchgate.net/publication/3 42869548_How_democracies_die Diakses tanggal 13 Juli 2021 